\title{
Canonical Vocalization and Phonological Development in Children with and without Repaired Cleft Palate
}

\author{
Ho Kim ${ }^{a}$, Seunghee $\mathrm{Ha}^{\mathrm{b}}$ \\ ${ }^{a}$ Department of Speech-Language Pathology and Audiology, Graduate School of Hallym University, Chuncheon, Korea \\ ${ }^{b}$ Division of Speech pathology and Audiology, Audiology E Speech Pathology Research Institute, Hallym University, Chuncheon, Korea
}

Correspondence: Seunghee $\mathrm{Ha}, \mathrm{PhD}$

Division of Speech Pathology and Audiology, Institute of Audiology \& Speech Pathology, Hallym University, 1 Hallimdaehak-gil, Chuncheon 24252, Korea

Tel: +82-33-248-2215

Fax: $+82-33-256-3420$

E-mail: shha@hallym.ac.kr

Received: July 5, 2021

Revised: August 6, 2021

Accepted: August 6, 2021

\begin{abstract}
Objectives: Canonical vocalization is an important factor in predicting the early speechlanguage development of children. This study investigated the characteristics of canonical vocalization and phonological development in children aged 13-16 months with cleft palate at 2-3 months following palatal surgery compared to those of children without cleft palate. Methods: Sixteen children with repaired cleft palate and 16 children without cleft palate participated in the study. The frequency and percentage of canonical vocalization, phoneme inventory, and phonological structures were analyzed from all-day recordings at home and compared between children with and without repaired cleft palate. The relationship between canonical vocalization and phonological development was also examined. Results: Children with repaired cleft palate had a lower rate of canonical vocalization and showed restriction in consonant inventories containing canonical vocalization compared to children without cleft palate. They produced nasals predominantly showing restricted production of stops, and they showed significantly smaller high vowel production than children without cleft palate. They also showed restrictions in the diversity and complexity of phonological structures compared to children without cleft palate. All groups had positive correlations between canonical vocalization ratio and phonological development. Conclusion: This study provided understanding about the phonological development of children with cleft palate following palatal surgery and addressed clinical implications for early intervention.
\end{abstract}

Keywords: Cleft palate, Palatal surgery, Canonical vocalization, Phonological development
아동은 출생 후 약 1 년 동안 옹알이 시기를 거쳐 점차 의미 있는 낱말을 산출하기 시작한다. 전형적으로 발달하는 아동은 10-12개 월경 첫 낱말을 산출하고, 18 개월경에 약 50-100개의 단어 또는 구 를 산출하며, 더불어 다양한 말소리를 산출하면서 초기 음운 발달 단계에 들어서게 된다(Bates et al., 1994). 이러한 일련의 과정을 거 치는 초기 말-언어 발달은 옹알이 시기에 산출하는 발성과 높은 관 련이 있다. 많은 선행연구에서는 옹알이 시기의 음절성 발성을 아 동의 초기 말-언어 발달을 예측할 수 있는 중요한 요인으로 주목하 고 있다(Ferguson \& Farwell, 1975; Ha, 2017; Jang \& Ha, 2020; McCune \& Vihman, 2001; Oller, Wieman, Doyle, \& Ross, 1976; Park
\& Ha, 2016; Schwartz \& Leonard, 1982; Stoel-Gammon \& Cooper, 1984; Storkel, 2006; Vihman, Macken, Miller, Simmons, \& Miller, 1985). 따라서, 영유아 시기 아동들의 음절성 발성 발달의 특징을 살펴보고 그 특성을 이해하는 것은 이후 말-언어 발달에서 나타날 수 있는 음운론적 문제를 조기에 선별하고 적절한 중재를 제공할 수 있는 발판이 될 수 있다.

영유아 시기 아동의 초기 발성은 의미 있는 낱말을 산출하는 시 기와 구별하기 위해 언어이전기 발성(prelinguistic vocalizations)이 라고 지칭하기도 한다. 이는 울음, 웃음, 딸꾹질, 트림과 같은 반사 적, 생리적인 소리를 포함하는 구어 같지 않은 발성(nonspeech-like 
vocalization)과 말 산출을 위한 전제 기술로 여겨지고 성인의 말소 리와 유사한 형태의 소리를 나타내는 구어 같은 발성(speech-like vocalization)으로 크게 분류할 수 있다(Oller, 2000). 아동의 초기 발성은 조음기관의 구조적, 기능적 능력이 발달하면서 순차적으로 나타난다. Nathani, Ertmer와 Stark (2006)는 아동의 초기 발성 발 달 과정을 살펴보기 위해 The Stark Assessment of Early Vocal Development-Revised (SAEVD-R)를 제안하였다. SAEVD-R은 아동 의 발성을 음향음성학적 특징을 바탕으로 23 개의 유형으로 분류하 고, 발달 순서에 따라 5 단계로 구분하고 있다. 먼저 1 단계는 생후부 터 약 2 개월까지의 발성으로 울음, 칭얼거림, 유사 공명음 그리고 생 리적인 소리가 대부분을 차지하고, 2 단계는 약 1-4개월에 나타나는 완전 공명음, 자음 유사 소리, 모음 유사 소리 등을 포함한다. 이후 3 단계는 약 3-8개월에 나타나는 단일 모음, 연속 모음, 활음, 들숨 소 리, 고함 소리, 경계선 옹알이 등이 있으며, 4단계는 약 5-10개월에 나타나는 반복적 옹알이가 있다. 마지막으로 5단계는 약 9-18개월 에 나타나는 변형적 옹알이와 자곤이 있다. 선행연구와 같이 초기 발성을 세부적인 분류 기준을 통해 여러 가지 유형과 발달 단계로 구분할 수 있으나, 최소 한 개 이상의 자음과 모음이 결합되어 초기 음운 발달이 시작되는 시점을 기준으로 크게 전음절성 발성(precanonical vocalization)과 음절성 발성(canonical vocalization)으 로도 분류할 수 있다. 이러한 이분법적인 분류 기준은 음절성 발성 이 이후 말-언어 발달과 밀접한 관계가 있다는 것에 초점을 맞춘 측 면에서 보다 적절할 수 있으며, 음절성 발성 내에서 나타나는 음운 발달을 집중적으로 살펴보는데 용이할 수 있다.

구체적으로 음절성 발성이란 자음과 모음이 결합된 기본 음절 (canonical syllable)을 포함하는 발성으로, 일반적으로 아동이 한 호흡에 산출한 발화를 일컫는다. 이러한 기본 음절은 완전 공명핵 과 상후두 조음기제(혀, 입술, 턱 등)의 운동으로 인해 생성되는 자 음 유사 소리(consonant-like sound or margin)를 포함하고, 그 사 이의 포먼트 전이 구간이 $120 \mathrm{~ms}$ 미만으로 짧은 것이 특징이다(Oller, 2000). 일반 아동의 경우 생후 4-6개월부터 음절성 발성을 산출하 기 시작하며, 늦어도 10 개월 이전까지 대부분 산출하게 된다(Lee, Jhang, Relyea, Chen, \& Oller, 2018). 이와 같은 음절성 발성은 언어 이전기 발성 이후에 나타나는 초기 어휘의 기본적인 구조를 이루며 음운 능력의 기초가 되어 이후 말 산출에 영향을 미친다고 알려져 있다(Nathani et al., 2006; Oller, 1980; Oller, Eilers, Neal, \& Schwartz, 1999; Stark, 1980; Stoel-Gammon, 1988; Vihman, 1992; Vihman et al., 1986). 선행연구에서는 아동이 음절성 발성에서 습득한 음소 로 이루어진 어휘는 더욱 빠르고 빈번하게 사용하지만, 음절성 발 성에서 산출되지 않은 음소가 포함된 어휘는 산출에서 지연을 보
일 수 있다고 보고하였다(Ferguson \& Farwell, 1975; Schwartz \& Leonard, 1982; Storkel, 2006). 또한 음절성 발성에서 출현된 음운 구조의 복잡성 및 다양성은 이후 유사한 음운 구조를 가진 어휘를 산출하는 데 선호하는 패턴을 만들게 된다. 이러한 패턴은 초기 낱 말의 형태와 다양성을 예측할 수 있는 요인으로써 보고되었으며, 이로 인해 언어이전기 음절성 발성의 중요성이 더욱 강조되었다(Ferguson, Peizer, \& Weeks, 1973; Hong \& Shim, 2002; Menn, 1976; Stoel-Gammon, 1988). 이에 따라 많은 선행연구에서는 일반 아동 뿐만 아니라 선천적인 기질적 장애를 가진 구개열, 청각장애, 다운 증후군 아동을 대상으로 음절성 발성에 대한 연구를 진행하였다 (Cobo-Lewis, Oller, Lynch, \& Levine, 1996; Chapman, HardinJones, Schulte, \& Halter, 2001; Ertmer, Young, \& Nathani, 2007; Ha, 2017, 2019; Iyer \& Ertmer, 2014; Jang \& Ha, 2020; Park \& Ha, 2016; Pi \& Ha, 2017). 그중 구개열 아동은 생후 12개월경에 구개 수 술을 통해 일반 아동과 동일한 조음기제를 갖추게 되기 때문에 수 술 이후 구개열 아동의 음절성 발성 발달을 추적하여 살펴보는 것 이 후기 말-언어 발달을 예측하는데 중요할 수 있다.

생후부터 구개 수술 이전까지 구개열 아동은 구강 내 입천장 및 연인두의 선천적인 구조적 결함으로 인해 말 발달에 어려움을 겪을 수 있다(Chapman, 1991; Chapman et al., 2001; Ha, 2014; Kuehn \& Moller, 2000; McWilliams, Morris, \& Shelton, 1990; Park \& Ha, 2016; Pi \& Ha, 2017). 구개 수술 이전의 구개열 아동은 불완전한 구 개의 형성으로 인해 치조와 구개 위치에서 산출되는 소리 습득에 어려움을 보이며(Lohmander-Agerskov, Söderpalm, Friede, \& Lilja, 1998; Trost-Cardamone, 1990), 더불어 연인두의 형성부전으로 인해 고압력 자음을 산출하는 데에도 제한을 보인다(Chapman et al., 2001; Grunwell \& Russell, 1987; Grunwell \& Russell, 1988; O' Gara \& Logemann, 1988; Peterson-Falzone, Trost-Cardamone, Karnell, \& Hardin-Jones, 2006). 이러한 말 산출 문제의 결과로 구 개 수술 이전의 구개열 아동은 일반 아동에 비해 전체 발성에서 음 절성 발성의 산출 비율이 제한적이며(Chapman et al., 2001), 음절 성 발성의 출현 시기가 지연되는 양상을 보이게 된다 $(\mathrm{Ha}, 2017, \mathrm{Ha}$, 2019; Scherer, Boyce, \& Martin, 2013).

구개열 아동은 구조적인 결함으로 인한 말 산출 상의 어려움을 최소화하기 위해 일반적으로 생후 12 개월경에 구개 수술을 실시하 게 된다. 구개 수술을 통해 구개열 아동은 불완전했던 조음기제가 재건됨으로써 정상적인 말 산출을 하기 위한 잠재력을 갖게 된다. 선행연구에서 수술 후 구개열 아동은 전체 발성에서 전음절성 발성 의 비율이 감소하였으며, 보다 더 다양한 형태의 음절성 발성을 산 출하였다(Park \& Ha, 2016). 또한 수술 후 2개월이 경과된 아동에 
Ho Kim, et al. • Phonological Development in Children with Repaired Cleft Palate

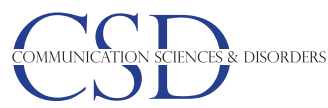

게서 구강마찰음과 구강파열음이 출현하기 시작하였고, 점차적으 로 구강 앞쪽 소리 산출의 증가를 확인할 수 있었다(Grunwell \& Russell, 1987, 1988). 그러나 구개 수술 후에 구개열 아동은 말 발달 상의 향상이 관찰되기는 하나 일반 아동에 비교해 여전히 음절성 발성의 양과 구조 면에서 부족하였다(Park \& Ha, 2016). 수술 후 3-4개월이 경과된 이후에도 고압력 자음 산출의 제한이 지속되었 으며(Eshghi, Vallino, Baylis, Preisser, \& Zajac, 2017), 상대적으로 비강 자음과 활음은 빈번하게 산출하였다(Chapman, 1991; Jones, Champman, \& Hardin-Jones, 2003; O'Gara \& Logemann, 1988). 모음의 경우에도 수술 후에도 남아있는 불완전한 연인두 폐쇄로 인해 모음의 비성화(nasalization)가 두드러지고, 특히 고모음에서 지각하기 어려운 특성을 보이기도 한다(Krakow, Beddor, Goldstein, \& Flower 1988). 이와 같은 수술 후 구개열 아동의 지속적인 말 문제 는 이후 언어기 표현언어 발달에 부정적인 영향을 끼칠 수 있다.

구개열 아동 중 약 $50 \%$ 가 수술 후에도 말 발달상의 지속적인 어 려움을 경험한다(Chapman et al., 2008; Willadsen, 2012). 특히 구 개 수술 이후 3 개월 이내의 말소리 산출은 구개열 아동이 조기 중 재 대상자로서 포함되어야 할지 결정할 수 있는 중요한 지표가 될 수 있어 체계적이고 정확한 분석이 필요하다(Hardin-Jones, Chapman, \& Scherer, 2006; Peterson-Falzone et al., 2006). 수술 후 3개 월 이내 구개열 아동의 음절성 발성 및 음운 발달에 대한 세부적인 평가는 언어기 단계에서 발생할 수 있는 말-언어 문제를 예측하고, 조기 중재의 필요성에 대한 객관적인 근거가 될 수 있다. 구개열 아 동의 음절성 발성과 관련된 기존의 국내 연구에서는 주로 발성의 유형 및 비율만을 살펴본 연구가 대다수이며( $\mathrm{Ha}, 2019 ; \mathrm{Kim} \& \mathrm{Ha}$, 2013), 음운 목록, 음운 구조와 같은 음운 발달을 살펴본 연구들은 대부분 18 개월 이상의 아동을 대상으로 언어기 낱말을 분석하였 다(Ha, 2014; $\mathrm{Pi} \& \mathrm{Ha}, 2017,2018)$. 수술 후 구개열 아동의 음절성 발 성 내에서 나타나는 음운 특성이 이후 말-언어 발달을 예측할수 있 는 중요한 요인으로 보고되어 그 관심이 증가되고 있음에도 불구하 고 여전히 이와 관련된 국내 연구는 부족한 실정이다. 또한 현재까 지 구개열 아동의 음운 발달과 관련하여 이루어진 대부분의 선행 연구들은 실험실 혹은 가정에서 부모 또는 검사자와 상호작용을 통해 수집된 한 시간 미만의 발성 표본을 연구 자료로 사용하였다 (Estrem \& Broen, 1989; Ha, 2014; Lohmander, Olsson, \& Flynn, 2011; Moon \& Ha, 2012; Park \& Ha, 2016; Pi \& Ha, 2017; Willadsen \& Albrechtsen, 2006). 이와 같이 자연스럽지 않은 환경 내에서 짧은 시간에 걸쳐 수집된 발성 자료는 아동의 실제 수행력을 대표 하는데 한계가 있으며 한정적인 정보를 제공할 수 있다. 그러므로 자연스럽고 일상적인 환경에서 충분한 시간 동안 수집된 자료를 기
반으로 아동의 발성 특성을 자세히 살펴보는 것이 필요하다.

Park과 $\mathrm{Ha}$ (2016)는 구개열 아동의 음절성 발성을 종단적으로 살펴봄으로써 수술 전, 후 구개열 아동의 음절성 발성과 음운 발달 의 변화를 살펴볼 수가 있었다. 그러나 표본 수가 10 명 이내로 제한 적이었으며, 약 30 분 정도의 짧은 시간 동안 산출된 발성을 토대로 연구가 진행된 한계점이 있었다. 또한 음운 발달과 관련된 음운 구 조를 발화(utterance) 단위가 아닌 음절(syllable) 단위로 구분하여 측정하였다. 이러한 음절 단위의 음운 구조 분석은 음절성 발성의 핵심인 기본 음절에 초점을 맞추어 체계적으로 분석할 수 있는 이 점이 있으나, 발화 길이에 대한 정보를 포함할 수 없으며 발화 내에 서 자음과 모음이 교대로 산출되어 발화를 구성하는 구조를 설명 하기에는 한계가 있다. 영유아기 아동들은 음절성 발성을 산출하 기 시작하면서 자신의 발성과 성인의 단어에 대한 유사성을 인식하 기 시작하며, 그러한 인식은 아동에게 "말 운동 계획(vocal motor schemes)"이라는 루틴을 생성할 수 있도록 기여하게 된다(McCune \& Vihman, 1987, 2001). 이와 같은 루틴은 초기 아동의 발화에서 나타나게 되고 이후 산출되는 초기 낱말 출현에 영향을 미치게 된 다. 이에 따라 아동의 초기 발성에서 나타나는 음절성 발성을 발화 단위로 살펴보는 것이 이후 말-언어 발달을 예측하는 요인으로서 보다 더 적절할 수 있다.

본 연구에서는 이와 같은 선행연구를 참고하고, 한계점을 보완 하여 적용하고자 한다. 첫째, 수술 후 2-3개월이 경과된 구개열 아 동을 대상으로 하여 아동의 초기 발성을 살펴보고자 한다. 수술 후 2-3개월의 기간은 구개열 아동이 변화된 조음기제에 적응하여 본 격적인 말소리 산출이 관찰되는 시기로, 이 시기에는 수술 전과 비 교해 구강 압력 자음의 출현이 관찰되며 구강 앞쪽 소리 산출의 증 가가 나타난다(Grunwell \& Russell, 1987, 1988). 이러한 수술 후 말 소리 산출의 변화 양상은 조기 중재에 중요한 지표로서 작용할 수 있다(Hardin-Jones et al., 2006; Peterson-Falzone et al., 2006). 따라 서, 본 연구에서는 구개 수술 후 3 개월 이내에 나타나는 말 발달의 중요성을 고려하여 수술 후 약 2-3개월이 경과된 시점의 아동을 연 구대상으로 하고자 한다. 둘째, 초기 발성 연구에 사용되고 있는 언 어 환경 분석기(Language ENvironmental Analysis, LENA)를 통 해(Ha, 2019; Ha \& Oller, 2019; Jang \& Ha, 2020) 자연스러운 가정 환경 내에서 12 시간 이상 수집된 수술 후 구개열 아동과 일반 아동 의 발성을 분석하고자 한다. 셋째, 수술 후 구개열 아동과 일반 아동 의 발성을 발화 단위로 구분하고 발화에서 나타나는 음절성 발성 의 특성을 분석하고자 한다. 구체적으로, 두 집단 간 음절성 발성의 특성을 살펴보기 위해 음절성 발성 산출률, 음운 목록(자음 목록, 조음방법 및 조음위치별 자음 산출률, 모음 유형별 산출률), 음운 
구조에서 어떠한 차이를 보이고 있는지 살펴보고자 한다. 마지막으 로 수술 후 구개열 아동과 일반 아동의 음절성 발성 산출률과 자음 목록 수, 음운 구조 유형 수 간의 상관관계를 비교하여 살펴봄으로 써 음절성 발성 산출과 음운 발달 간의 관계를 확인하고 수술 후 구 개열 아동의 발성 발달 패턴이 일반 아동과 유사한 양상을 보이고 있는지 알아보고자 한다.

\section{연구방법}

\section{연구대상}

본 연구는 13-16개월의 (구순)구개열 아동 16명, 일반 아동 16명 을 대상으로 진행하였다. 일반 아동은 남아 8 명, 여아 8 명으로 검사 자-부모 인터뷰에서 신체적, 신경학적 또는 정서 등의 문제를 보이 지 않고 정상 발달하는 것으로 보고되었다.

구개열 아동은 수술 후 2-3개월이 경과된 시점의 아동을 연구 대 상으로 선정하였다. 대상자는 남아 7명, 여아 9명으로 구개열 이외 신체적, 신경학적 또는 정서 등의 문제가 없었고, 말 문제로 인한 언 어치료 경험이 없었다. 구개열 아동 집단 중 구순과 구개 모두에서 파열을 보이는 아동(구순구개열)은 11 명, 구개에만 파열을 보이는 아동(구개열)은 5 명이었다.

대상자의 성별, 월령, 수술시기에 대한 정보는 Table 1에 제시하였 다. 두 집단 간 평균 생활연령을 비교하였을 때 구개열 아동 평균 14.44 개월, 일반 아동 평균 14.05 개월이었다. 또한 구개열 아동의 경 우 평균 11.94개월에 구개 수술을 받았으며 자료 수집 시에는 평균 2.5 개월이 경과된 시점이었다. 구개열 아동과 일반 아동의 생활연 령에서 통계적으로 유의미한 차이가 있는지 살펴보기 위해 독립표 본 $t$-검정(independent $t$-test)을 실시한 결과, 두 집단 간 생활연령에 따른 차이는 유의미하지 않았다 $\left(t_{(30)}=-.229, p=.821\right)$.

\section{자료수집}

본 연구의 모든 절차는 한림대학교 생명윤리위원회의 승인을 받 아 진행하였다(No. HIRB-2018-033). 본 연구에서는 연구자가 아동 의 가정에 직접 방문하여 부모 면담 및 LENA 녹음기 사용법을 전

Table 1. Participants' information

\begin{tabular}{lccc}
\hline & Gender (boy:girl) & Age $(\mathrm{mo})$ & Age at palatoplasty $(\mathrm{mo})$ \\
\hline CP group $(\mathrm{N}=16)$ & $7: 9$ & $14.44(.81)$ & $11.94(.57)$ \\
NCP group $(\mathrm{N}=16)$ & $8: 8$ & $14.05(.73)$ & \\
Total $(\mathrm{N}=36)$ & $15: 17$ & $14.47(.76)$ & \\
\hline
\end{tabular}

Values are presented as mean (SD).

$\mathrm{CP}=$ children with cleft palate; $\mathrm{NCP}=$ noncleft children .
달하는 것으로 자료 수집을 실시하였다. 연구자는 아동의 기본정 보 및 발달현황을 조사하기 위해 사례면담지를 이용하여 부모면담 을 진행하였다. 사례면담지는 임신 및 출산 시 특이사항, 출산 후 대 상자의 건강상의 문제 유무, 수술력, 청력 수준 등의 항목들로 구성 되어 있다. 면담을 종료한 후에는 주양육자에게 LENA 녹음기와 녹음기를 부착할 수 있는 아동용 조끼를 제공하였으며, 사용방법 에 대해 충분히 설명을 하였다. LENA 녹음기는 소형 녹음기이며, 이 기기를 통하여 하루 동안(약 16 시간) 자연스러운 환경에서 산출 되는 아동의 발성을 녹음할 수 있다. 녹음은 방문을 기준으로 2주 내에 하루를 정해 아동이 아침에 깨어난 시점부터 잠이 들 때까지 최 소 12 시간 이상 연속적으로 발성을 녹음할 수 있도록 요청하였다.

\section{자료분석}

자료분석은 주 양육자가 LENA 녹음기를 이용하여 약 12 시간 동안 수집한 발성 자료를 사용하였다. LENA 녹음기로 녹음된 발 성 자료는 자동 분석 프로그램인 LENA pro (LENA Research Foundation)를 이용하여 발성 표본을 5 분 단위로 구분하고, 아동의 발 성이 가장 많이 산출된 상위 20 개의 표본을 선정하여 총 100 분의 자료를 추출하였다. 추출된 자료는 Action Analysis Coding and Training (AACT; Delgado, Buder, \& Oller, 2010) 프로그램을 사용 하여 분석하였다. AACT 프로그램은 아동의 초기 발성 연구를 위 해 개발된 프로그램으로 입력된 음원을 듣고 실시간으로 측정치 코딩이 가능하며, 소리의 파형과 스펙트로그램이 제시됨에 따라 청 지각적 판단에 추가적인 도움을 줄 수 있는 이점이 있다. 모든 자료 분석은 제 1 저자가 하였으며 Ha와 Oller (2019)가 제시한 바와 같이 초기 발성 분석을 위해 약 20 시간 이상 집중적으로 듣기 훈련 및 분 석 훈련을 받았다. 또한 암맹 분석을 위해 대상자의 정보(월령, 성별, 구개열 유무, 구개열 수술 시기 등)는 분석자에게 제공되지 않았다.

분석을 위한 아동의 발성은 호흡단위(발화)로 분절하였으며, 호 흡의 경계가 모호한 때에는 발화 간 2 초 이상의 심 구간이 지속될 경우 다른 하나의 발성으로 분류하였다(Nathani et al., 2006).

아동의 발성 중 1 ) 양육자의 말소리 또는 주변 환경음(소음)과 중 첩하여 명확한 판단이 어려울 경우, 2) 칭얼거림, 울음 또는 웃음 소 리, 3) 딸꾹질, 트림 등 생리적으로 발생하는 소리, 4) 힘을 주거나, 5) 섭식 시 발생하는 소리의 경우에는 분석에서 제외하였다. 본 연구 에 참여한 아동의 연령을 고려하면 발화 중 실제 의미 있는 낱말을 사용한 경우가 있을 수 있다. 그러나 언어이전기 발성과 낱말을 구 별하기 위해서는 문맥 내에서 의사소통 의도를 파악함과 동시에 음성학적으로 낱말과 유사한 형태인지 판단해야 하므로 정확히 언 어이전기 발성과 의미 있는 낱말을 구별하기 어려울 수 있다(Har- 
din-Jones \& Chapman, 2014). 따라서 본 연구에서는 언어이전기 발 성과 낱말을 따로 구별하지 않고, 위에 기술한 소리를 제외하고 아 동이 산출한 모든 구어 같은 발성(speech-like vocalization)을 분석 하였다.

음운 목록은 SynKD 1.5.2 (일명 깜짝새)를 사용하여 분석하였 다. 깜짝새 프로그램은 한글 말뭉치 분석을 위해 개발된 프로그램 으로 입력된 말뭉치의 음절 단위, 초· 중· 종성의 자소 단위의 검색 이 가능하다. 초기 발성과 말 특성에 대해 집중적인 훈련을 받은 제 1 저자가 음절성 발성을 듣고 음성 전사한 내용을 깜짝새 프로그램 에 입력하였다. 입력된 음성 전사 내용은 프로그램을 통해 자소 단 위로 구분되었으며, 각 자음과 모음 유형에 따라 분류되었다.

\section{발성 유형}

발성 유형은 Oller (2000)와 $\mathrm{Ha}$ (2017)에서 언급한 조작적 정의 를 토대로 하여 발화 내에 자음과 모음이 포함된 기본 음절의 유무 에 따라 전음절성 발성과 음절성 발성으로 구분하여 살펴보았다. 하나의 발화에 전음절성 발성과 음절성 발성이 동시에 출현하였을 때는 보다 상위의 산출 단계로 알려져 있는 음절성 발성을 선택하 여 음절성 발화로 간주하였다. 이에 따른 음절성 발성 산출률은 (음절성 발성 수/전체 발성 수) $\times 100$ 으로 계산하였다. 또한 음운 발 달 특성을 살펴보기 위해 발성 유형 중 음절성 발성은 음성 전사를 하였다. 음성 전사는 최대 5 번을 듣고도 명확히 전사할 수 없는 경 우에는 분석에서 제외하였다.

\section{전음절성 발성}

자음과 모음이 결합된 기본 음절 또는 활음이 포함되지 않은 발 화이거나, 성문음 또는 인두음만을 포함하거나 공명핵과 자음 유 사 소리 사이의 포먼트 전이구간이 $200 \mathrm{~mm} / \mathrm{s}$ 이상으로 긴 경우를 포함한다(Oller, 2000).

\section{음절성 발성}

자음과 모음이 결합된 기본 음절 또는 활음을 포함하고 있는 발 화 형태이다. 기본 음절은 완전 공명핵과 상후두 조음기제의 운동 으로 인해 생성되는 자음 유사 소리, 그리고 짧은 포먼트 전이구간 을 반드시 포함한다(Oller, 2000). 추가적으로 본 연구에서는 소곤 거리는 발성도 음절성 발성에 포함하였다. Nathani 등(2006)은 소 곤거리는 발성을 발성 단계 중 확장 단계(Expansion level)보다 상 위 단계인 기본 음절성 발성 단계(basic canonical syllables level)에 포함시켰다. 소곤거리는 발성(whispered vocalizations)의 경우 완 전 공명핵이 포함되어 있지 않지만, 완전 공명핵을 포함하는 발성
보다 더 많은 노력이 필요하다. 소곤거리는 발성은 성대의 진동 없 이 후두 위에서 공기의 마찰에 의해 생성되는 난류성 소음으로부 터 기원 되며(Eckert \& Laver, 1994), 이를 위해 정교한 감각 운동 제 어가 필요하다(Mansell, 1973; Tsunoda, Niimi, \& Hirose, 1994; Tsunoda, Ohta, Niimi, Soda, \& Hirose, 1997). 따라서, 본 연구에서 도 Nathani 등(2006)과 동일하게 소곤거리는 발성을 음절성 발성 으로 포함하였다.

활음의 경우 한국어권에서는 자음으로 구분하지 않지만, 혀, 입 술, 턱 등의 상후두 조음기제의 움직임이 포함되어 자음과 유사한 조음 및 음성 특성이 나타나기 때문에 활음이 포함된 음절을 기본 음절과 함께 분류하였다(Ha \& Oller, 2019).

\section{음운 목록}

음운 목록은 음절성 발성 내에서 관찰되는 자음과 모음 유형에 따라 분류하여 정리하였다. 자음 목록은 안정적인 산출을 고려해 적어도 3 번 이상 관찰된 자음만을 목록에 포함시켰다(Chapman,

1991; Salas-Provance, Kuehn, \& Marsh, 2003; Stoel-Gammon, 1985). 집단 간 산출되는 자음의 특성을 살펴보기 위해 조음위치 및 조음 방법별 자음 산출의 평균 빈도 및 비율을 구하였다. 조음위치 및 조 음방법별 자음 산출률은 (조음위치별 자음 산출 수 또는 조음방법 별 자음 산출수/전체 산출된 자음수) $\times 100$ 으로 계산하였다.

아동의 발성에서 2 음절 이상의 발화를 산출할 때, 후행되는 초성 자음이 경음이나 격음일 경우 음운규칙의 영향을 받아 종성이 발 현된 것처럼 느껴질 수 있기 때문에 종성의 존재가 모호하게 지각 될 수 있다(예: [아따]/[앋따], [아타]/[앋타] 등). 또한 동일한 비음 ([ㅁ], [ㄴ])이 연쇄적으로 산출될 때는 음성적으로는 하나의 연속 적인 조음 동작으로 실현되는 하나의 소리로 초성과 종성으로 구 분하는 것이 모호할 수 있다(예: [음마], [안나] 등). 따라서 자음 목 록은 음절 내의 위치에 따라 구분하지 않고 통합하여 제시하였다. 그리고 본 연구에서는 음절성 발성 내에 포함된 성문마찰음 [히는 자음 목록에 포함하였으나, 성문파열음, 인두파열음, 인두마찰음 과 같은 보상조음의 경우에는 자음 목록에 포함시키지 않았다. 자 음 목록은 한국어 음소를 기준으로 하였기 때문에 한국어 음소에 해당하지 않는 보상조음은 목록에서 제외하였다. 구개열 아동 중 5 명은 발성 수준에서도 보상 조음이 관찰되는 것으로 나타났다.

모음은 영유아기 아동의 경우 혀의 움직임보다 하악의 움직임이 모음 산출에 지배적이며, 이러한 하악의 움직임의 정도에 따라 모 음의 높이 차원으로 분류하여 나타낼 수 있다(Davis \& MacNeliage, 1995). 이에 따라 모음을 혀의 전, 후 보다 하악의 높낮이에 초 점을 맞추어 고모음([l], [-T]), 중모음([-1]], [H], [-], [H], [ㄱ]), 저 
모음([] ])으로 구분하였다. 모음 [-_]는 음운론적 측면에서는 고모 음으로 구분되지만, 모음 [ ] ], [ T ] 와 달리 고모음으로 명확하게 지 각되지 않는다(Hare, 1983; Paschall, 1983). 특히 영유아기 아동의 경우 발달상 하악의 운동 범위가 제한적일 수 있어 모음 [-] 산출 시 중모음에 보다 가깝게 지각될 수 있다. 따라서 본 연구에서는 모 음 [-] 를 중모음으로 분류하였다. 모음 유형별 산출률은 (각 모음 유형 수(전체 모음 수) $\times 100$ 으로 계산하였다.

\section{음운 구조 유형}

음운 구조는 아동의 음절성 발성을 토대로 분석하였다( $\mathrm{V}:$ 모음, $\mathrm{C}$ : 자음, $\mathrm{G}:$ 활음). 발화 단위를 기준으로 분석한 음절성 발성 구조 는 7가지 유형(예: VC, GV, GVC, CV, CGV, CVC, CGVC)으로 고 정된 형태의 구조가 있는 음절 단위의 분석과 달리, 산출된 발화마 다 포함된 음절의 수가 다양하므로 산출된 발화의 모든 음운 구조 유형을 살펴보았다. 음운 구조 유형은 안정적인 산출을 고려하여 3 회 이상 관찰된 유형만을 음운 구조의 유형으로 구분하여 살펴보 았다.

\section{신뢰도}

전체 발성 자료 중 $20 \%$ 를 임의로 선정하여 분석자 내/간 신뢰도 를 구하였다. 분석자 내 신뢰도는 자료 분석 후 2 개월 이후에 다시 분석하여 구하였고, 분석자 간 신뢰도는 제 1 저자와함께 초기 발성 듣기 및 분석 훈련을 받은 언어병리학 전공 대학원생 1 명이 자료를 분석한 결과로 구하였다. 발성 유형에 대한 신뢰도를 두 데이터 집 합 사이의 상관계수로 나타낸 결과, 분석자 내 신뢰도는 $r=.98$, 분 석자 간 신뢰도는 $r=.96$ 으로 산출되었다. 또한 음절성 발성을 전사 한 자료에 대한 신뢰도를 산출한 결과, 음절 수에 대한 일치도(음절 수 분석 결과가 일치한 발성 수/총 음절성 발성 수 $\times 100)$ 는 분석자 내 신뢰도에서 $90.63 \%$, 분석자 간 신뢰도에서 $84.66 \%$ 였다. 음절 수 가 일치한 음절성 발성에서 나타난 음소와 음운 구조에 대한 일치 도를 살펴본 결과, 분석자 내 신뢰도는 각각 $89.59 \%, 90.26 \%$ 로 나타 났고, 분석자 간 신뢰도는 각각 $78.00 \%, 76.19 \%$ 로 나타났다.

Table 2. The number of total vocalizations, the percentage of canonical vocalization and the number of consonant inventories in canonical vocalizations

\begin{tabular}{lccc}
\hline & CP group (N=16) & NCP group (N=16) & $t$ \\
\hline No. of total vocalizations & $713.19(298.99)$ & $824.75(327.82)$ & -1.006 \\
Canonical vocalization (\%) & $23.47(12.36)$ & $42.20(16.78)$ & $-3.593^{* *}$ \\
No. of consonant inventories & $6.56(3.40)$ & $12.81(3.63)$ & $-5.018^{* * *}$ \\
\hline
\end{tabular}

Values are presented as mean (SD).

$\mathrm{CP}=$ children with cleft palate; $\mathrm{NCP}=$ noncleft children .

${ }^{* *} p<.01,{ }^{* * *} p<.001$.

\section{통계분석}

본 연구는 SPSS ver. 25.0 프로그램을 활용하여 통계분석을 실시 하였다. 통계처리는 집단 간 총 발성 수, 음절성 발성 산출률, 자음 목록 수, 조음위치 및 조음방법별 자음 산출률, 모음 유형별 산출 률 그리고 음운 구조 유형 수가 유의미한 차이를 보이는지 살펴보 기 위해서 각각 독립표본 $t$-검정(Independent $t$-test)을 실시하였다. 유의수준은 다중 $t$-검정의 사용과 관련하여 제 1 형 오류(type $1 \mathrm{er}-$ ror)의 높은 확률을 방지하기 위해 본페로니 교정(Bonferroni correction)을 적용하여 조정하였다(Huberty \& Morris, 1989). 본페로 니 교정을 적용한 유의수준은 .05 를 검사 횟수로 나눈 값으로 적용 하였다. 또한 각 집단에서 음절성 발성 산출률에 따른 자음 목록 수, 음운 구조 유형 수 간의 상관관계를 살펴보기 위해 pearson 상 관분석(Pearson Correlation Analysis)을 실시하였다.

\section{연구결과}

\section{총 발성 수 및 음절성 발성 산출률}

구개열 아동과 일반 아동의 총 발성 수와 음절성 발성 산출률은 Table 2 에 제시하였다. 총 100 분의 발성 자료에서 나타난 구개열 아 동과 일반 아동의 총 발성 수를 살펴본 결과, 총 발성 수에서는 유의 미한 차이가 없었다 $\left(t_{(30)}=-1.006, p=.323\right)$. 두 아동 집단 간 음절성 발성 산출률은 일반 아동 평균 $42.20 \%$, 구개열 아동 평균 $23.47 \%$ 로 일반 아동이 구개열 아동보다 유의미하게 높은 산출률을 나타 냈다 $\left(t_{(30)}=-3.593, p<.01\right)$.

\section{자음 목록}

구개열 아동과 일반 아동의 음절성 발성에서 관찰된 자음 목록 수는 Table 2에 제시하였으며, 각 집단 간 자음 목록 수의 차이를 살 펴본 결과, 일반 아동은 평균 12.81 개, 구개열 아동은 평균 6.56 개로 일반 아동이 구개열 아동보다 2 배가량 더 많은 자음 목록 수를 보 였으며, 이는 통계적으로 유의하였다 $\left(t_{(30)}=-5.018, p<.001\right)$. 두 아 동 집단별 $50 \%$ 이상의 대상자에게 포함된 자음 목록을 제시한 $\mathrm{Ta}-$ ble 3 를 살펴보면, 일반 아동은 비음뿐만 아니라 모든 파열음이 자 음 목록에 포함된 반면에 구개열 아동은 비음과 연구개 파열음만 이자음 목록에 포함되었다.

Table 3. Phones in consonant inventories of $50 \%$ of subjects

\begin{tabular}{l}
$\frac{\text { CP group }}{m, n, y, k} m, n, y, p, p^{*}, p^{h}, t, t^{*}, t^{h}, k, k^{*}, k^{h}, t c^{*}, h$ \\
\hline$C P=$ children with cleft palate; $N C P=$ noncleft children.
\end{tabular}




\section{조음방법 및 조음위치별 자음 산출률}

\section{조음방법별 자음 산출률}

구개열 아동과 일반 아동의 조음방법별 자음 산출의 빈도 및 비 율의 평균과 표준편차는 Table 4에 제시하였다. 자음 산출률 분석은 아동이 산출한 전체 자음에서 이루어졌다. 집단 간 전체 자음 대비 조음방법별 자음 산출률의 차이를 살펴보면 파열음 $\left(t_{(30)}=-6.268\right.$, $p<.001)$, 비음 $\left(t_{(30)}=5.950, p<.001\right)$ 에서 유의한 차이를 보였으며 유음 $\left(t_{(30)}=-.016, p=.987\right)$, 파찰음 $\left(t_{(30)}=-1.643, p=.111\right)$, 마찰음 $\left(t_{(30)}=.484, p=.632\right)$ 에서는 유의한 차이를 보이지 않았다. 통계적 으로 유의한 차이를 보인 파열음과 비음에 대한 집단 간 자음 산출 률을 살펴보면 파열음은 일반 아동 평균 $48.03 \%$, 구개열 아동 평균 $12.46 \%$ 로 일반 아동이 구개열 아동보다 높았다. 비음은 일반 아동 평균 $48.90 \%$, 구개열 아동 평균 $85.03 \%$ 로 구개열 아동이 일반 아동 보다 더 높았다. 즉, 구개열 아동이 산출한 자음은 대부분 비음이었 으며, 파열음은 주로 연구개 파열음 [ㄱ] 만이 포함되어 전체 자음 에서 차지하는 비율이 낮았다.

\section{조음위치별 자음 산출률}

구개열 아동과 일반 아동의 조음위치별 자음 산출 빈도 및 비율 의 평균과 표준편차는 Table 5에 제시하였다. 조음위치별 자음 산 출률은 아동이 음절성 발성에서 산출한 전체 자음에서 분석이 이 루어졌다. 집단 간 전체 자음 대비 조음위치별 자음 산출률의 차이 는 양순 $\left(t_{(30)}=2.926, p<.01\right)$ 위치에서만 유의하였으며, 일반 아동 평균 $42.47 \%$, 구개열 아동 평균 $60.55 \%$ 로 일반 아동보다 구개열 아 동에게서 양순음이 상대적으로 더 높은 비율을 차지하였다.

\section{파열음 및 비음의 조음위치별 산출률}

구개열 아동과 일반 아동 간 유의미한 차이를 보였던 파열음 및 비음의 조음위치별 빈도 및 비율의 평균을 Figure 1에 제시하였다. Figure 1은 구개열 아동과 일반 아동 간 양순, 치조, 연구개 위치에

Table 4. The frequency and percentage of consonant by manner of articulation

\begin{tabular}{|c|c|c|c|c|c|}
\hline \multirow{2}{*}{ Manner } & \multicolumn{2}{|c|}{$\mathrm{CP}$ group $(\mathrm{N}=16)$} & \multicolumn{2}{|c|}{ NCP group $(N=16)$} & \\
\hline & Frequency & $(\%)$ & Frequency & $(\%)$ & \\
\hline Plosives & $44.94(65.40)$ & $12.46(11.50)$ & 356.06 (279.54) & $48.03(19.56)$ & $-6.268^{* *}$ \\
\hline Nasals & 283.31 (219.78) & $85.03(12.93)$ & 292.50 (173.13) & 48.90 (20.55) & $5.950^{* *}$ \\
\hline Liquids & $2.13(3.34)$ & $.71(1.25)$ & $6.63(9.74)$ & $.71(.88)$ & -.016 \\
\hline Affricates & .88 (2.18) & .41 (1.22) & $8.13(9.00)$ & $1.16(1.37)$ & -1.643 \\
\hline Fricatives & 3.31 (3.42) & $1.37(1.38)$ & & $1.17(0.91)$ & .484 \\
\hline
\end{tabular}

Values are presented as mean (SD).

$\mathrm{CP}=$ children with cleft palate; $\mathrm{NCP}=$ noncleft children .

${ }^{* *} p<.001$ (alpha level is .05 divided by the number of tests).
서 차지하는 파열음 및 비음의 평균 빈도와 비율을 제시하고 있다. Figure 1을 살펴본 결과, 일반 아동이 구개열 아동보다 양순, 치조, 연구개 위치 모두에서 높은 자음 산출 빈도를 보였다. 집단 간 각 조 음위치별 파열음 및 비음의 산출률을 살펴보면, 일반 아동은 양순 위치에서 비음의 산출이 더 높았고, 치조, 연구개 위치에서 파열음 의 산출률이 상대적으로 높았다, 반면에 구개열 아동은 양순, 치조 위치에서 비음 산출률이 대략 $90 \%$ 로 대부분을 차지하고 있었으 며, 연구개 위치에서는 [ㄱ] 산출로 인해 양순과 치조 위치에 비해 상대적으로 높은 파열음 산출률을 보였다.

\section{모음 유형별 산출률}

구개열 아동 집단과 일반 아동 집단의 모음 산출률은 Table 6에 제시하였다. 두 아동 집단 간 음절성 발성 내에서 산출된 모음(고모 음, 중모음, 저모음)의 평균 비율을 살펴보면 고모음에서만 통계적 으로 유의한 차이를 보였다 $\left(t_{(30)}=-3.078, p<.016\right)$. 고모음 산출률 은 일반 아동이 구개열 아동보다 높게 나타났다(Table 6).

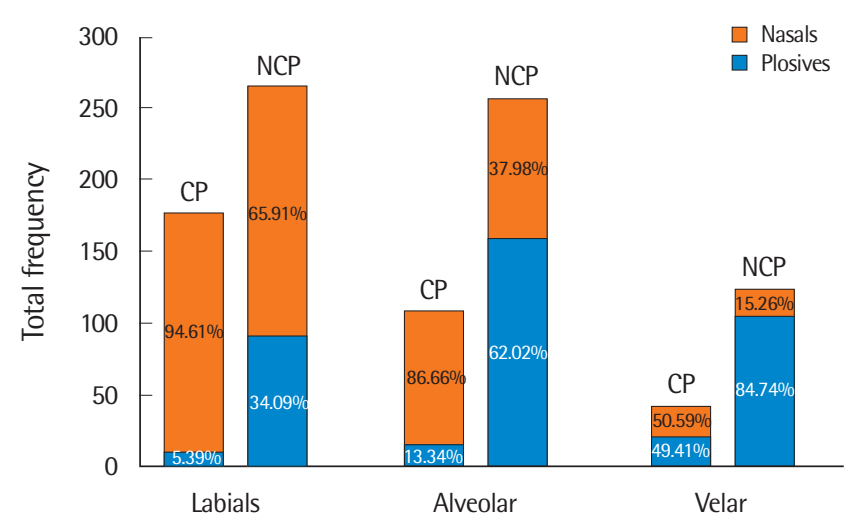

Figure 1. The frequency and percentage of plosives and nasals by place of articulation by each group.

$\mathrm{CP}=$ children with cleft palate; $\mathrm{NCP}=$ noncleft children .

Table 5. The frequency and percentage of consonant by place of articulation

\begin{tabular}{|c|c|c|c|c|c|}
\hline \multirow{2}{*}{ Place } & \multicolumn{2}{|c|}{$\mathrm{CP}$ group $(\mathrm{N}=16)$} & \multicolumn{2}{|c|}{ NCP group $(N=16)$} & \\
\hline & Frequency & $(\%)$ & Frequency & $(\%)$ & \\
\hline Labials & 177.31 (124.95) & $60.55(19.40)$ & $266.38(175.70)$ & $42.47(15.32)$ & $2.926^{*}$ \\
\hline Alveolar & 110.94 (158.74) & 23.71 (18.14) & 265.81 (200.12) & $36.06(14.15)$ & -2.145 \\
\hline Palatal & $.88(2.18)$ & $.41(1.22)$ & $8.13(9.00)$ & $1.16(1.37)$ & -1.643 \\
\hline Velar & 42.25 (60.13) & $12.89(11.94)$ & 124.13 (97.52) & $19.23(13.51)$ & -1.406 \\
\hline Glottal & 3.19 (3.22) & $1.36(1.39)$ & 7.06 (8.49) & $1.06(.85)$ & .726 \\
\hline
\end{tabular}

Values are presented as mean (SD).

$\mathrm{CP}=$ children with cleft palate; $\mathrm{NCP}=$ noncleft children .

${ }^{*} p<.01$ (alpha level is .05 divided by the number of tests). 
Table 6. The percentage of vowel by height of the mandible

\begin{tabular}{lccc}
\hline & CP group $(\mathrm{N}=16)$ & NCP group $(\mathrm{N}=16)$ & $t$ \\
\hline High & $5.76(2.29)$ & $10.95(6.34)$ & $-3.078^{*}$ \\
Mid & $44.88(11.87)$ & $45.60(11.47)$ & -.174 \\
Low & $49.35(12.25)$ & $43.44(13.59)$ & 1.291
\end{tabular}

Values are presented as mean (SD).

$\mathrm{CP}=$ children with cleft palate; $\mathrm{NCP}=$ noncleft children .

${ }^{*} p<.016$ (alpha level is .05 divided by the number of tests).

\section{음운 구조 유형}

두 집단 간 음운 구조 유형 수의 차이를 살펴본 결과, 일반 아동 $(\mathrm{M}=19.31, \mathrm{SD}=9.31)$ 이 구개열 아동 $(\mathrm{M}=10.81, \mathrm{SD}=6.30)$ 보다 음 운 구조 유형의 수가 유의미하게 높았다 $\left(t_{(30)}=-3.023, p<.05\right)$.

두 집단에서 $50 \%$ 이상의 대상자에게 나타난 음운 구조 유형과 음운 구조 유형별 대상자의 사용 비율을 Table 7에 제시하였다. Table 7을 살펴보면, $50 \%$ 이상의 대상자가 공통적으로 사용한 음운 구조 유형은 구개열 아동 8 개, 일반 아동 14 개로 나타나 일반 아동 이 구개열 아동보다 다양한 발성 구조를 산출하고 있음을 확인할 수 있었다. 각 집단에서 가장 우세하게 나타난 상위 3 개의 유형은 공통적으로 $\mathrm{VCV}, \mathrm{CV}, \mathrm{VC}$ 가 있었다. $\mathrm{VCV}$ 는 두 집단에서 $100 \%$ 의 대상자에게서 나타났다. CV는 일반 아동의 경우 $100 \%$ 의 대상자에 게서 나타났고, 구개열 아동의 경우 일부 대상자를 제외한 $87.5 \%$ 의 대상자에게서 나타났다. $\mathrm{VC}$ 는 구개열 아동 $81.25 \%$, 일반 아동 $93.75 \%$ 의 대상자에게서 나타났고 각 집단에서 세 번째로 우세한 음운 구 조로 나타났다. 발성 시작 시 첫 소리의 양상을 살펴보면, 구개열 아 동의 경우 자음으로 시작하는 발성이 $\mathrm{CV}, \mathrm{CVCV}, \mathrm{CVV}$ 로 3개가 나 타났고, 일반 아동의 경우 $\mathrm{CV}, \mathrm{CVCV}, \mathrm{CVCVCV}, \mathrm{CVC}, \mathrm{CVV}$ 로 5 개 가 나타났다. $\mathrm{CV}, \mathrm{CVCV}, \mathrm{CVV}$ 는 두 집단 모두에서 나타났으나 일 반 아동이 구개열 아동보다 더 높은 사용률을 보였다. 발화 길이 측 면에서는 구개열 아동이 최대 3음절(e.g., $\mathrm{VCVCV})$, 일반 아동이 최 대 4음절(e.g., VCVCVCV)로 나타나 일반 아동이 구개열 아동보다 더 긴 발화를 산출하는 것으로 나타났다.

\section{음절성 발성 산출률과 자음 목록 수, 음운 구조 유형 수 간의 상관 관계}

구개열 아동과 일반 아동의 음절성 발성 산출률과 자음 목록 수, 음운 구조 유형 수간의 관계를 살펴보기 위해 pearson 상관분석을 실시한 결과, 일반 아동에서는 음절성 발성 산출률과 자음 목록 수 $(r=.788, p<.01)$, 음절성 발성 산출률과 음운 구조 유형 수 $(r=.803$, $p<.01)$ 모두에서 유의한 정적상관을 보였다. 마찬가지로 구개열 아 동에서도 음절성 발성 산출률과 자음 목록 수 $(r=.697, p<.01)$, 음
Table 7. Predominant utterance structures of children with and without CP

\begin{tabular}{|c|c|c|}
\hline Ranking & $\mathrm{CP}$ group $(\mathrm{N}=16)$ & $\mathrm{NCP}$ group $(\mathrm{N}=16)$ \\
\hline 1 & VCV (100\%) & CV (100\%) \\
\hline 2 & CV (87.5\%) & VCV (100\%) \\
\hline 3 & VC (81.25\%) & VC (93.75) \\
\hline 4 & VGV (75\%) & CVCV (87.5\%) \\
\hline 5 & CVCV (62.5\%) & CVCVCV (81.25\%) \\
\hline 6 & VCVCV (62.5\%) & VGV (81.25\%) \\
\hline 7 & GV $(56.25 \%)$ & CVC (75\%) \\
\hline 8 & CVV (50\%) & VCCV (75\%) \\
\hline 9 & & VCVCV (75\%) \\
\hline 10 & & GV (75\%) \\
\hline 11 & & CWV (68.75\%) \\
\hline 12 & & VCWV (68.75\%) \\
\hline 13 & & WCV (56.25\%) \\
\hline 14 & & VCVCVCV (56.25\%) \\
\hline
\end{tabular}

Utterance structure inventory (percentage of subjects).

$\mathrm{CP}=$ children with cleft palate; $\mathrm{NCP}=$ noncleft children; $\mathrm{C}=$ consonant; $\mathrm{G}=$ glide; $\mathrm{V}=$ vowel.

절성 발성 산출률과 음운 구조 유형 수 $(r=.748, p<.01)$ 모두에서 유의한 정적상관을 보였다.

\section{논의 및 결론}

본 연구는 수술 후 구개열 아동과 생활 연령이 일치하는 일반 아 동을 대상으로 발화에서 나타나는 음절성 발성과 음운 발달의 특 성을 비교하여 살펴보았다. 특히 본 연구는 수술 후 2-3개월이 경과 된 아동을 대상으로 통제하여 진행하였다. 구개열 아동은 수술 후 2-3개월 동안 회복 기간을 거치고 정상적인 조음기제를 안정적으 로 갖추게 된다. 또한 정상적인 조음기제를 갖추게 되면서 수술 전 불완전한 조음기제로 인해 산출에 어려움이 있었던 소리들을 경험 하고 연습하는 시간을 갖게 된다. 변화된 기제에 적응하는 기간을 통해 구개열 아동은 본격적으로 말 산출을 할 준비를 마치게 된다. 이러한 과정을 고려하였을 때, 수술 후 2-3개월이 경과된 시점은 초 기 말-언어 발달의 예후를 예측할 수 있는 중요한 시기일 것이다 (Hardin-Jones et al., 2006; Peterson-Falzone et al., 2006). 따라서 본 연구에서는 수술 후 2-3개월이 경과된 구개열 아동의 음절성 발 성과 음운 발달의 특성을 체계적으로 살펴보고 일반 아동의 발달 양상과 비교하여 제시하고자 하였다.

먼저 구개열 아동과 일반 아동의 총 발성 수를 비교하여 살펴본 결과, 집단 간 유의미한 차이를 보이지 않았다. 구개열 아동의 총 발 성 수와 관련된 선행연구를 살펴보면 결과는 일관적이지 않았다. 일부 선행연구에서는 구개열 아동이 일반 아동보다총 발성 수에서 
더 적은 결과를 보였지만(Chapman, 1991; Ha, 2017; Philips \& Kent, 1984), 다른 선행연구에서는 집단 간 유의한 차이가 없었다(Chapman et al., 2001; Scherer, Williams, \& Proctor-Williams, 2008). 집 단 간 총 발성 수에서 차이가 있다고 보고한 선행연구는 주로 적은 수의 아동을 대상으로 연구를 진행하였고, 아동이 낮선 검사자와 함께 있는 상황에서 수집된 1 시간 미만의 짧은 발성을 분석하였다. 하지만 본 연구는 자연스러운 환경인 가정에서 하루 동안 수집된 발성을 분석하였기 때문에 보다 타당한 결과라고 할 수 있다. 일반 적으로 발성의 양은 아동이 조음기제를 탐색하면서 소리 산출을 연습하는 시간과 직접적으로 관련이 있기 때문에 선천적인 장애를 지닌 아동은 보통 발성의 양이 적고, 이후 말 발달에 부정적인 영향 을 끼친다고 알려져 왔다(Belardi et al., 2017; Iyer, Denson, Lazar, \& Oller, 2016). 본 연구에서 구개열 아동이 일반 아동과 비슷한 양 으로 발성을 산출한다는 결과는 말 발달상 긍정적인 면으로 해석 할 수 있는 동시에 구개열 아동의 말 특성은 발성의 양보다는 다른 면에서 일반 아동과 구별될 수 있음을 의미한다.

구개열 아동은 일반 아동과 비슷한 양의 발성을 산출했음에도 불구하고 전체 발성에서 음절성 발성이 차지하는 비율이 유의하게 낮았다. 음절성 발성 산출률에서 구개열 아동은 $23.47 \%$ 로 나타났 고, 일반 아동은 $42.20 \%$ 로 나타나 일반 아동이 구개열 아동에 비 해 약 2 배 정도 더 높은 비율을 보였다. 이러한 결과는 구개열 아동 을 대상으로 하여 전체 발성에서 차지하는 음절성 발성의 비율을 살펴본 선행연구와 일관성이 있다(Chapman et al., 2001; Ha, 2019). 구개열 아동은 구개 수술 전 반복적으로 발생하는 중이염으로 인 한 일시적인 청력 손실과 불완전한 조음기제로 인해 다양한 자음 을 지각 및 변별하고 산출을 하는데 어려움을 겪을 수 있다. 또한 수술 후에도 새롭게 변화된 기제에 적응하는 노력이 필요함에 따 라 자음 산출이 다소 지연되어 음절 산출에 제한을 보이는 것으로 여겨진다.

음절성 발성에 포함된 자음 목록을 각 집단별로 살펴보면 자음 목록 수에서는 일반 아동 12.81 개, 구개열 아동 6.56개로 구개열 아 동이 일반 아동보다 유의하게 적은 수의 자음을 산출하였다. Park 과 $\mathrm{Ha}$ (2016)는 15 개월경 일반 아동의 경우 7.78개, 구개열 아동의 경우 3.25 개의 자음 목록을 보인다고 보고하였는데 수치상으로는 두 연구 결과가 다르지만 구개열 아동이 일반 아동의 절반 정도의 적은 자음 목록 수를 보인다는 점에서는 일관성이 있다. 본 연구와 Park과 Ha (2016)에서 나타난 자음 목록 수의 차이는 발성 수집 방 법에 따른 차이로 해석할 수 있다. 선행연구에서는 낮선 검사자에 의해 수집된 30 분간의 발성 자료를 분석하였으나 본 연구는 가정 에서 주 양육자에 의해 수집된 12 시간 이상의 발성 중 아동의 발성
이 가장 많이 산출된 100 분의 발성 자료를 분석하였다. 이와 같은 발성 수집 시 환경적, 시간적인 차이가 자음 목록의 양적인 면에서 상이한 결과를 나타낸 것으로 사료된다. 집단별 $50 \%$ 이상의 대상 자에게서 산출된 자음 목록을 살펴보면 구개열 아동은 [ㅁ, ᄂ, O, 기가, 일반 아동은 [ㅁ, ᄂ, O, ㅂ, 뻐, 프, ᄃ, 匹, E, ᄀ, ㄱ, ㄱ, 쪼, 히가 포함되었다. 일반 아동은 다양한 비음뿐만 아니라 다양한 구 강 압력 자음을 산출하는 반면에 구개열 아동은 수술 후 2-3개월 이 지난 후에도 비음만을 산출하고 구강 압력 자음을 산출하는데 여전히 제한을 보였다. 구개열 아동을 대상으로 음운 발달을 살펴 본 선행연구에서는 비음과 더불어 성문마찰음 [히과 같은 뒤쪽 소 리의 주된 산출을 보고하였다(Moon \& Ha, 2012; Park \& Ha, 2016). 하지만 본 연구에서는 음절성 발성에 포함된 자음 목록만을 살펴 보았기 때문에 [히의 실제적인 산출을 살펴보기에는 제한이 있었 다. 본 연구는 음절성 발성을 '상후두 조음기제(혀, 입술, 턱 등)의 움 직임에 의해 발생한 자음이 포함된 발성'으로 정의하였기 때문에 (Oller, 2000), 발화에서 독립적으로 [히만 산출되었을 경우에는 전 음절성 발성으로 간주하여 분석하였다. 따라서 본 연구의 결과는 집단 간 전음절성 발성에서 나타난 [히의 산출을 자음 목록에 포 함하지 않아 선행연구 결과와 다소 다르게 나타났다. 그럼에도 불 구하고 대다수의 구개열 아동의 자음 목록에서 비음을 제외한 연 구개 파열음 [기만이 유일하게 나타난 것을 고려하면, 구개열 아동 이 뒤쪽 소리를 선호하는 특징이 보인다고 할 수 있다.

각 집단에서 산출한 전체 자음을 조음방법 및 조음위치별로 살 펴보면, 먼저 조음방법별로 일반 아동은 파열음 산출이 유의하게 높았고 구개열 아동은 비음 산출이 유의하게 높았다. 구개열 아동 은 수술 전 구강과 비강의 연결로 인해 파열음 산출의 어려움을 겪 는다. 수술 이후에도 연인두의 폐쇄가 일관적으로 이루어지지 않 아(Eshghi et al., 2017), 구강 내 높은 압력을 유지하는 데 어려움을 보여 파열음 산출에 제한을 보일 수 있다. 영어권 구개열 아동의 파 열음 산출과 연인두 폐쇄 기능을 관련하여 살펴본 Eshghi 등(2017) 에 따르면 구개 수술 후 3-4개월이 경과되어도 파열음 산출 시 연인 두의 폐쇄가 일관적이지 않았고, 수술 후 7 개월이 경과되어서야 모 든 대상자에게서 일관적인 연인두 폐쇄가 보였음을 보고하였다. 본 연구에 참여한 구개열 아동도 수술 후 2-3개월이 경과되었지만 여 전히 연인두 폐쇄에 어려움을 보이고, 그로 인해 파열음을 전혀 산 출하지 못하거나, 적게 산출하고 있었다.

집단 간 조음위치별 자음 산출률을 살펴보면, 구개열 아동이 일 반 아동보다 양순음에서 유의하게 높은 산출률을 보였다. 본 연구 는 이러한 결과가 두 집단 모두에서 조음방법별 자음 산출의 대부 분을 차지하고 있는 파열음 및 비음의 산출과 관련이 있다고 사료 
되어, 집단 간 파열음 및 비음의 조음위치별 산출 빈도 및 비율의 평 균을 살펴보았다. 결과적으로, 구개열 아동은 일반 아동에 비해 파 열음 산출이 거의 모든 조음위치에서 적게 산출되었으며, 양순과 치조 위치에서 산출된 소리는 대부분 비음이었다. 특히, 양순 위치 에서 비음 산출률은 $94.61 \%$ 로 상당한 수치를 보였다. 이러한 결과 를 종합하여 살펴보았을 때, 구개열 아동이 일반 아동에 비해 양순 음에서 더 높은 산출률을 보인 것은 구개열 아동의 경우 조음위치 별로 자음이 다양하게 산출되지 않고, 양순 비음 [ㅁ]의 산출을 한 정적으로 사용하고 있기 때문으로 볼 수 있다. 오히려 파열음의 경 우 양순음과 같은 앞쪽 소리가 아닌 연구개 파열음 [ㄱ] 와 같은 뒤 쪽 소리를 선호하는 경향을 보였다. 이와 같은 결과는 구개열 아동 들이 조음 위치 측면에서 양순 비음과 연구개 파열음 또는 인두, 성 문 파열음과 같은 보상조음의 빈번한 산출로 인해 성도의 최전방 (입술), 최후방(연구개, 인두, 성문)에서 산출되는 소리를 선호한다 고 보고한 선행연구와 일관성을 보였다(O'Gara \& Logemann, 1988).

집단 간 음절성 발성에서 나타나는 모음 유형별 산출률을 살펴 보면, 구개열 아동이 일반 아동에 비해 고모음에서 유의하게 낮은 비율을 보였다. Willadsen과 Albrechtsen (2006)은 12개월의 덴마 크권 구개열 아동의 언어이전기 발성에서 혀의 전, 후와 구강 개방 의 정도에 따라 4 가지 유형으로 구분하여 살펴보았다. 모음의 유형 을 분류하는 데에서 본 연구와 차이가 있지만 구개열 아동이 고모 음에서 유의하게 낮은 산출률을 보인 결과는 일치하였다. 그러나 이러한 결과는 해석에 주의가 필요하다. 구개열 아동은 수술 후에 도 연인두 폐쇄 부전이 지속될 수 있기 때문에 모음을 산출함에 있 어 어느 정도의 비성화(nasalization)가 나타날 수 있으며, 이러한 비 성화는 청자가 고모음을 지각하는데 어려움을 야기할 수 있다(Krakow et al., 1988). 즉, 본 결과에 나타난 고모음 산출의 저하는 구개 열 아동이 고모음의 산출을 회피하는 것일 수도 있고, 혹은 잔존하 는 연인두 폐쇄 부전으로 인한 고모음의 비성화 현상으로 청자가 정확하게 인식하는 데 어려움이 있어 나타난 결과일 수도 있다.

선행연구에서는 구개열 아동이 수술 후에도 지속적으로 보이는 연인두 기능상의 제한으로 인해 자음 목록의 제한과 함께 복잡한 음운 구조 산출 상의 어려움을 보인다고 보고하였다(Chapman et al., 2001; Moon \& Ha, 2012; Park \& Ha, 2016; Philips \& Kent, 1984). 본 연구에서도 구개열 아동이 수술 후에도 자음 목록과 함께 음운 구조에서 제한을 보이는 것으로 나타났다. 음절성 발성을 구성하 고 있는 음운 구조 유형 수를 살펴보면, 일반 아동은 19.31개, 구개 열 아동은 10.81 개의 음운 구조를 보여 일반 아동에 비해 음운 구조 의 다양성과 복잡성 면에서 떨어졌다. 집단별 $50 \%$ 이상의 대상자에 게 보인 음운 구조 유형으로는 구개열 아동의 경우 $\mathrm{VCV}, \mathrm{CV}, \mathrm{VC}$,
$\mathrm{VGV}, \mathrm{CVCV}, \mathrm{VCVCV}, \mathrm{GV}, \mathrm{CVV}$ 순으로 보였으며, 일반 아동의 경 우 CV, VCV, VC, CVCV, CVCVCV, VGV, CVC, VCCV, VCVCV, $\mathrm{GV}, \mathrm{CVV}, \mathrm{VCVV}, \mathrm{VVCV}, \mathrm{VCVCVCV}$ 순으로 관찰되었다. 구개열 아동은 일반 아동에 비해 발성에서 나타나는 음운 구조가 다양하 지 못했고 상대적으로 단순한 형태를 보였으며 발화 길이에서도 보 다짧은 것을 확인할 수 있었다. 또한 집단 간 동일하게 나타난음운 구조 유형의 사용 빈도를 살펴보았을 때, $\mathrm{VCV}$ 를 제외한 모든 음운 구조 유형에서 비교적 낮은 빈도를 보였다. 발성의 첫소리 유형을 살펴보면 구개열 아동은 일반 아동과 비교하여 상대적으로 모음으 로 시작하는 음운 구조 유형이 상위권을 차지하였고, 자음으로 시 작하는 음운 구조 유형은 상대적으로 적었다. 이러한 결과는 파열 음 산출에 어려움으로 인해 구개열 아동이 발성의 첫소리에서 주로 모음 또는 비음 만을 주로 사용함을 의미한다. $\mathrm{Ha}$ (2014)는 구개열 아동이 일반 아동에 비해 초기 어휘의 첫소리에서 모음으로 시작 하는 낱말의 비율이 높은 것으로 보고하였다. 구개열 아동의 음운 구조에 대한 본 연구와 $\mathrm{Ha}$ (2014)의 연구결과를 종합하면 제한적 인 음운 구조나 특정 음운 구조에 대한 선호도는 이후 표현 어휘 상 의 제한 또는 특징으로 이어질 수 있음을 의미한다.

각 집단에서 음절성 발성 산출률과 자음 목록 수, 음운 구조 유 형 수 간의 상관관계를 살펴보면, 일반 아동과 구개열 아동 모두 음 절성 발성 산출률과 자음 목록 수, 음절성 발성 산출률과 음운 구 조 유형 수에서 정적상관을 보여, 음절성 발성 산출률이 자음 목록, 음운 구조와 같은 음운 발달과 밀접한 관련이 있음을 보여주었다. 즉, 일반 아동과 구개열 아동 모두 음절성 발성 산출률이 높을수록 다양한 자음과 음운 구조를 산출하는 것을 알 수 있었다. 구개열 아동은 일반 아동에 비해 상대적으로 낮은 상관계수를 보였는데, 이는 수술 후 2-3개월이 경과된 시점에 구개열 아동은 음절성 발성 의 산출에 비해 자음과 음운 구조 산출의 다양성이 다소 떨어짐을 나타낸다. 이는 구개열 아동이 비음과 $\mathrm{VCV}, \mathrm{VC}, \mathrm{CV}$ 와 같은 한정적 인 자음과 음운 구조만을 산출하는 경향이 있다고 볼 수 있다.

본 연구는 수술 후 구개열 아동과 일반 아동의 발성에서 나타나 는 음절성 발성과 음운 발달의 특성을 비교하여 살펴볼 수 있었다. 수술 후 구개열 아동의 음절성 발성 및 음운 발달은 중이염으로 인 한 말소리 변별 및 지각에 어려움, 달라진 조음기제에 대한 적응 및 미숙한 사용, 잔존하는 연인두 폐쇄부전 등으로 인해 일반 아동에 비해 말 발달의 모든 측면에서 지연되었을 가능성이 있다. 특히 수 술 후 변화된 조음기제의 안정기로 볼 수 있는 2-3개월이 경과된 시 점에서도 파열음 산출은 연구개 파열음 [기와 같이 뒤쪽 소리에서 제한적으로 나타났고 비음 산출이 대부분을 차지하고 있음을 관 찰할 수 있었다. 구개 수술 후 양순, 치조 위치에서 파열음의 산출은 
Ho Kim, et al. • Phonological Development in Children with Repaired Cleft Palate

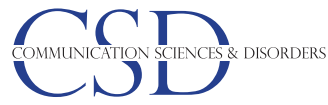

구개 수술이 성공적으로 이루어졌음을 짐작할 수 있게 하며, 이후 말-언어 발달에 예후를 예측할 수 있는 중요한 요인으로 작용한다 (Jones et al., 2003, Zajac et al., 2021). 따라서 본 연구결과는 구개열 아동은 수술 이후 수술 부위가 회복되고 안정기에 들 무렵부터 파 열음 산출을 강화할 수 있는 조기 중재 프로그램을 적용하는 것이 필요함을 시사한다. 구개열 아동은 생후부터 수술 전까지 반복적 인 중이염과 불완전한 조음기제로 인해 말 발달에 필요한 청각적, 촉각적 피드백의 기회가 적어 수술 후 일반 아동보다 더 집중적인 언어 자극을 제공하는 것이 필요하다. 3 세 이전의 아동은 직접적인 중재가 실질적으로 어려울 수 있기 때문에 아동의 일상 환경에서 풍부한 자극을 제공할 수 있는 주 양육자를 통한 간접 중재가 효과 적일 수 있다. 따라서 부모 교육 등의 조기 언어 중재를 통해서 음절 성 발성과 파열음을 포함한 다양한 말소리와 음운 구조 산출을 촉 진하여 이후 말-언어 발달에 긍정적인 영향을 미칠 수 있도록 해야 할 것이다.

\section{REFERENCES}

Bates, E., Marchman, V., Thal, D., Fenson, L., Dale, P., Reznick, J. S., ... \& Hartung, J. (1994). Developmental and stylistic variation in the composition of early vocabulary. Journal of Child Language, 21(1), 85-123.

Belardi, K., Watson, L. R., Faldowski, R. A., Hazlett, H., Crais, E., Baranek, G. T., ... \& Oller, D. K. (2017). A retrospective video analysis of canonical babbling and volubility in infants with Fragile X syndrome at 9-12 months of age. Journal of Autism and Developmental Disorders, 47(4), 1193-1206.

Cobo-Lewis, A. B., Oller, D. K., Lynch, M. P., \& Levine, S. L. (1996). Relations of motor and vocal milestones in typically developing infants and infants with Down syndrome. American Journal of Mental Retardation, 100(5), 456-467.

Chapman, K. L. (1991). Vocalizations of toddlers with cleft lip and palate. Cleft Palate-Craniofacial Journal, 28(2), 172-178.

Chapman, K. L., Hardin-Jones, M. A., Goldstein, J. A., Halter, K. A., Havlik, R. J., \& Schulte, J. (2008). Timing of palatal surgery and speech outcome. The Cleft Palate-Craniofacial Journal, 45(3), 297-308.

Chapman, K. L., Hardin-Jones, M., Schulte, J., \& Halter, K. A. (2001). Vocal development of 9-month-old babies with cleft palate. Journal of Speech, Language, and Hearing Research, 44(6), 1268-1283.

Davis, B. L., \& MacNeilage, P. F. (1995). The articulatory basis of babbling. Journal of Speech, Language, and Hearing Research, 38(6), 1199-1211.

Delgado, R. E., Buder, E. H., \& Oller, D. K. (2010). AACT (Action Analysis
Coding and Training). Miami, FL: Intelligent Hearing Systems.

Eckert, H., \& Laver, J. (1994). Menschen und ihre Stimmen: Aspekte der vokalen Kommunikation. Flensburg: Beltz.

Estrem, T., \& Broen, P. A. (1989). Early speech production of children with cleft palate. Journal of Speech, Language, and Hearing Research, 32(1), 1223.

Ertmer, D. J., Young, N. M., \& Nathani, S. (2007). Profiles of vocal development in young cochlear implant recipients. Journal of Speech Language Hearing Research, 50(2), 393-407.

Eshghi, M., Vallino, L. D., Baylis, A. L., Preisser, J. S., \& Zajac, D. J. (2017). Velopharyngeal status of stop consonants and vowels produced by young children with and without repaired cleft palate at 12, 14, and 18 months of age: a preliminary analysis. Journal of Speech, Language, and Hearing Research, 60(6), 1467-1476.

Ferguson, C. A., \& Farwell, C. B. (1975). Words and sounds in early language acquisition. Language, 51(2), 419-439.

Ferguson, C. A., Peizer, D. B., \& Weeks, T. E. (1973). Model-and-replica phonological grammar of a child's first words. Lingua, 31(1), 35-65.

Grunwell, P., \& Russell, J. (1987). Vocalisations before and after cleft palate surgery: a pilot study. International Journal of Language \& Communication Disorders, 22(1), 1-17.

Grunwell, P., \& Russell, J. (1988). Phonological development in children with cleft lip and palate. Clinical Linguistics \& Phonetics, 2(2), 75-95.

Ha, S. (2014). Phonological characteristics of early vocabulary in young children with cleft palate. Phonetics and Speech Sciences, 6(2), 65-71.

Ha, S. (2017). Longitudinal study of vocal development in 9-to 18-month-old children acquiring Korean. Communication Sciences \& Disorders, 22(3), 435-444.

Ha, S. (2019). Onset of canonical babbling in children with and without cleft palate. Communication Sciences \& Disorders, 24(3), 715-723.

Ha, S., \& Oller, D. K. (2019). Canonical babbling in Korean-acquiring infants at 4-9 months of age. Communication Sciences \& Disorders, 24(1), 1-8.

Hardin-Jones, M., Chapman, K., \& Scherer, N. J. (2006). Early intervention in children with cleft palate. The ASHA Leader, 11(8), 8-32.

Hardin-Jones, M., \& Chapman, K. L. (2014). Early lexical characteristics of toddlers with cleft lip and palate. The Cleft Palate-Craniofacial Journal, 51(6), 622-631.

Hare, G. (1983). Development at 2 years. Phonological Development in Children, 18(72), 55-85.

Hong, K., \& Shim, H. (2002). A longitudinal study of development of the in- 
fant's speech sounds: 18 to 24 months. Korean Journal of Communication \& Disorders, 7(2), 106-125.

Huberty, C. J., \& Morris, J. D. (1992). Multivariate analysis versus univariate analysis. In A. E. Kazdin (Ed.), Methodological issues and strategies in clinical research (1st ed., pp. 302-308). Washington, DC: American Psychological Association.

Iyer, S. N., Denson, H., Lazar, N., \& Oller, D. K. (2016). Volubility of the human infant: effects of parental interaction (or lack of it). Clinical Linguistics \& Phonetics, 30(6), 470-488.

Iyer, S. N., \& Ertmer, D. J. (2014). Relationships between vocalization forms and functions in infancy: preliminary implications for early communicative assessment and intervention. American Journal of Speech-Language Pathology, 23(4), 587-598.

Jang, H., \& Ha, S. (2020). Canonical babbling development in Korean-acquiring infants. Communication Sciences \& Disorders, 25(1), 104-112.

Jones, C. E., Chapman, K. L., \& Hardin-Jones, M. A. (2003). Speech development of children with cleft palate before and after palatal surgery. The Cleft palate-Craniofacial Journal, 40(1), 19-31.

Kim, M., \& Ha, S. (2013). Longitudinal study of early vocalization development in toddlers with and without cleft palate from 6 to 18 months of age. Communication Sciences \& Disorders, 18(2), 223-234.

Kuehn, D. P., \& Moller, K. T. (2000). Speech and language issues in the cleft palate population: the state of the art. The Cleft Palate-Craniofacial Journal, 37(4), 1-35.

Krakow, R. A., Beddor, P. S., Goldstein, L. M., \& Fowler, C. A. (1988). Coarticulatory influences on the perceived height of nasal vowels. The Journal of the Acoustical Society of America, 83(3), 1146-1158.

Lohmander-Agerskov, A., Söderpalm, E., Friede, H., \& Lilja, J. (1998). A comparison of babbling and speech at pre-speech level, 3 , and 5 years of age in children with cleft lip and palate treated with delayed hard palate closure. Folia Phoniatrica et Logopaedica, 50(6), 320-334.

Lohmander, A., Olsson, M., \& Flynn, T. (2011). Early consonant production in Swedish infants with and without unilateral cleft lip and palate and twostage palatal repair. The Cleft Palate-Craniofacial Journal, 48(3), 271-285.

Lee, C. C., Jhang, Y., Relyea, G., Chen, L. M., \& Oller, D. K. (2018). Babbling development as seen in canonical babbling ratios: a naturalistic evaluation of all-day recordings. Infant Behavior and Development, 50, 140-153.

Mansell, P. (1973). An experimental investigation of articulatory reorganisation in whispered speech. Forschungsberichte des Instituts für Phonetik und sprachliche Kommunikation der Universität München, 2, 201-253.
McCune, L., \& Vihman, M. M. (1987). Vocal motor schemes. Papers and Reports on Child Language Development, 26, 72-79.

McCune, L., \& Vihman, M. M. (2001). Early phonetic and lexical development. Journal of Speech Language and Hearing Research, 44(3), 670-684.

McWilliams, B. J., Morris, H., \& Shelton, R. (1990). Cleft palate speech. Philadelphia: B.C. Decker.

Menn, L. (1976). Pattern, control, and contrast in beginning speech (Doctoral dissertation), University of Illinois at Urbana-Champaign, Illinois, USA.

Moon, H., \& Ha, S. (2012). Phonological development in toddlers with cleft palate and typically developing toddlers aged 12-24 months. Korean Journal of Communication \& Disorders, 17(1), 118-129.

Nathani, S., Ertmer, D. J., \& Stark, R. E. (2006). Assessing vocal development in infants and toddlers. Clinical Linguistics \& Phonetics, 20(5), 351-369.

O’Gara, M. M., \& Logemann, J. A. (1988). Phonetic analyses of the speech development of babies with cleft palate. The Cleft Palate Journal, 25(2), 122134.

Oller, D. K. (1980). The emergence of the sounds of speech in infancy. In G. H. Yeni-Komshian, J. F. Kavanagh, \& C. A. Ferguson (Eds.), Child phonology. Vol. I: Production (pp. 93-112). New York: Academic Press.

Oller, D. K. (2000). The emergence of the speech capacity. Mahwah, NJ: Psychology Press.

Oller, D. K., Eilers, R. E., Neal, A. R., \& Schwartz, H. K. (1999). Precursors to speech in infancy: the prediction of speech and language disorders. Journal of Communication Disorders, 32(4), 223-245.

Oller, D. K., Wieman, L. A., Doyle, W. J., \& Ross, C. (1976). Infant babbling and speech. Journal of Child Language, 3(1), 1-11.

Paschall, L. (1983). Development at two years. Phonological Development in Children, 18(72), 73-81.

Park, B., \& Ha, S. (2016). Early vocalization and later phonological and expressive vocabulary development in children with and without cleft palate. Communication Sciences \& Disorders, 21(2), 355-370.

Peterson-Falzone, S. J., Trost-Cardamone, J. E., Karnell, M. P., \& Hardin-Jones, M. (2006). Effects of cleft and non-cleft VPI on speech in older children. In S. J. Peterson-Falzone (Ed.), The clinician's guide to treating cleft palate speech (pp. 17-39). St. Louis: Mosby Elsevier.

Philips, B. J., \& Kent, R. D. (1984). Acoustic-phonetic descriptions of speech production in speakers with cleft palate and other velopharyngeal disorders. In N. Lass (Ed.), Speech and language: advances in basic research and practice (Vol. 11, pp. 113-167). New York: Academic Press.

Pi, M., \& Ha, S. (2017). Phonological characteristics of early vocabulary among 
children with cleft palate, late talking children, and typically developing children. Communication Sciences \& Disorders, 22(2), 328-340.

Pi, M., \& Ha, S. (2018). Early and later phonological and language development of children with cleft palate. Communication Sciences \& Disorders, 23(2), 404-413.

Salas-Provance, M. B., Kuehn, D. P., \& Marsh, J. L. (2003). Phonetic repertoire and syllable characteristics of 15-month-old babies with cleft palate. Journal of Phonetics, 31(1), 23-38.

Scherer, N. J., Boyce, S., \& Martin, G. (2013). Pre-linguistic children with cleft palate: growth of gesture, vocalization, and word use. International Journal of Speech-Language Pathology, 15(6), 586-592.

Scherer, N. J., Williams, A. L., \& Proctor-Williams, K. (2008). Early and later vocalization skills in children with and without cleft palate. International Journal of Pediatric Otorhinolaryngology, 72(6), 827-840.

Schwartz, R. G., \& Leonard, L. B. (1982). Do children pick and choose? An examination of phonological selection and avoidance in early lexical acquisition. Journal of Child Language, 9(2), 319-336.

Stark, R. E. (1980). Stages of speech development in the first year of life. In G. H. Yeni-Komshian, J. F. Kavanagh, \& C. A. Ferguson (Eds.), Child phonology. Vol. I: Production (pp. 73-90). New York: Academic Press.

Stoel-Gammon, C. (1985). Phonetic inventories, 15-24 months: a longitudinal study. Journal of Speech, Language, and Hearing Research, 28(4), 505512.

Stoel-Gammon, C. (1988). Prelinguistic vocalizations of hearing-impaired and normally hearing subjects: a comparison of consonantal inventories. Journal of Speech and Hearing Disorders, 53(3), 302-315.

Stoel-Gammon, C., \& Cooper, J. A. (1984). Patterns of early lexical and phonological development. Journal of Child Language, 11(2), 247-271.

Storkel, H. L. (2006). Do children still pick and choose? The relationship between phonological knowledge and lexical acquisition beyond 50 words.
Clinical Linguistics \& Phonetics, 20(7-8), 523-529.

Trost-Cardamone, J. E. (1990). The development of speech: Assessing cleft palate misarticulations. In D. A. Kernahan \& S. W. Rosenstein (Eds.), Cleft lip and palate: A system of management (pp. 340-349). Baltimore: Williams \& Wilkins.

Tsunoda, K., Niimi, S., \& Hirose, H. (1994). The roles of the posterior cricoarytenoid and thyropharyngeus muscles in whispered speech. Folia Phoniatrica et Logopaedica, 46(3), 139-151.

Tsunoda, K., Ohta, Y., Niimi, S., Soda, Y., \& Hirose, H. (1997). Laryngeal adjustment in whispering: magnetic resonance imaging study. Annals of Otology, Rhinology \& Laryngology, 106(1), 41-43.

Vihman, M. (1992). Early syllables and the construction of phonology. In C. A. Ferguson, L. Menn, \& C. Stoel-Gammon (Eds), Phonological development: Models, research, implications (pp. 393-422). Timonium, MD: York Press.

Vihman, M. M., Ferguson, C. A., \& Elbert, M. (1986). Phonological development from babbling to speech: common tendencies and individual differences. Applied Psycholinguistics, 7(1), 3-40.

Vihman, M. M., Macken, M. A., Miller, R., Simmons, H., \& Miller, J. (1985). From babbling to speech: a re-assessment of the continuity issue. Language, $61(2), 397-445$.

Willadsen, E. (2012). Influence of timing of hard palate repair in a two-stage procedure on early speech development in Danish children with cleft palate. The Cleft Palate-Craniofacial Journal, 49(5), 574-595.

Willadsen, E., \& Albrechtsen, H. (2006). Phonetic description of babbling in Danish toddlers born with and without unilateral cleft lip and palate. The Cleft Palate-Craniofacial Journal, 43(2), 189-200.

Zajac, D. J., Vallino, L. D., Baylis, A. L., Adatorwovor, R., Preisser, J. S., \& Vivaldi, D. (2021). Emergence of prevocalic stop consonants in children with repaired cleft palate. Journal of Speech, Language, and Hearing Research, 64(1), 30-39. 


\section{국문초록}

\section{수술 후 구개열 아동과 일반 아동의 음절성 발성 및 음운 발달 김호' 하승희}

'한림대학교 일반대학원 언어병리청각학과, ${ }^{2}$ 한림대학교 언어청각학부, 청각언어연구소

배경 및 목적: 음절성 발성은 아동의 초기 말-언어 발달을 예측할 수 있는 중요한 요인이다. 본 연구는 수술 후 2-3개월이 경과된 13-16 개월의 구개열 아동과 일반 아동의 음절성 발성과 음운 발달의 특성에 대해서 살펴보았다. 방법: 수술 후 구개열 아동 16 명, 일반 아동 16 명이 연구에 참여하였다. 가정에서 12 시간 동안 수집된 각 집단의 발성 자료를 토대로 음절성 발성, 자음 목록, 모음 유형 그리고 음운 구조의 빈도 및 비율을 비교하였다. 이러한 측정치를 통해 음절성 발성과 음운 발달 간 관계를 살펴보았다. 결과: 구개열 아동은 수술 후 에도 음절성 발성 산출률이 일반 아동에 비해 낮았다. 음절성 발성에 포함된 자음 분석 결과, 자음 목록 수가 제한적이었으며, 조음방법 및 조음위치별 자음 산출 면에서는 비음이 전체 자음의 대부분을 차지하였고 파열음은 제한적이었으며 양순음에서 일반 아동과 유의 한 차이를 보였다. 모음 산출 분석 결과, 구개열 아동은 모음 산출시 일반 아동 보다 고모음 산출에 저하를 보였다. 음운 구조 면에서는 일반 아동에 비해 음운 구조의 다양성 및 복잡성 면에서 제한이 있었다. 각 집단은 모두 음절성 발성 산출률과 음운 발달 간의 정적상 관을 보였다. 논의 및 결론: 수술 후 구개열 아동의 음운론적 특징을 이해하고 그와 관련된 조기 중재에 대한 정보와 방향성을 제시할 수 있을 것으로 기대한다.

핵심어: 구개열, 구개 수술, 음절성 발성, 음운 발달

\section{참고문헌}

김민영, 하승희 (2013). 6-18 개월 구개열 영유아와 일반 영유아의 발성 발달에 관한 종단연구. Communication Sciences \& Disorders, 18(2), 223-234. 문희원, 하승희 (2012). 12-24 개월 구개열 유아와 일반 유아의 음운발달. 언어청각장애연구, 17(1), 118-129.

박보라, 하승희 (2016). 구개열, 일반 영유아의 초기 발성 및 음운, 표현어휘 발달 비교. Communication Sciences \& Disorders, 21(2), 355-370. 장현성, 하승희 (2020). 한국 아동의 음절성 옹알이 발달. Communication Sciences \& Disorders, 25(1), 104-112.

피민경, 하승희 (2017). 구개열 아동, 말 늦은 아동, 일반 아동의 초기 어휘에 나타난 음운 특성. Communication Sciences \& Disorders, 22(2), 328340 .

피민경, 하승희 (2018). 구개열 아동의 초기 표현언어지연 동반 여부에 따른 음운 및 언어 발달. Communication Sciences \& Disorders, 23(2), 404413.

하승희 (2014). 구개열 아동의 초기 어휘에 나타난음운 특성 연구. 말소리와 음성과학, 6(2), 65-71.

하승희 (2017). 9-18 개월 일반 한국 아동의 초기 발성에 대한 종단 연구. Communication Sciences \& Disorders, 22(3), 435-444.

하승희 (2019). 구개열 아동과 일반아동의 음절성 옹알이의 시작 시기. Communication Sciences \& Disorders, 24(3), 715-723.

하승희, D. Kimbrough Oller (2019). 4-9 개월 한국 아동의 음절성 옹알이. Communication Sciences \& Disorders, 24(1), 1-8.

홍경훈, 심현섭 (2002). 유아의 말소리 발달 특성: 18-24개월 종단연구. 언어청각장애연구, 7(2), 106-125.

\section{ORCID}

김 호(제1저자, 대학원생 https://orcid.org/0000-0003-1641-4737); 하승희(교신저자, 교수 https://orcid.org/0000-0003-2133-3720) 